\title{
The antiviral drug ribavirin does not mimic the 7-methylguanosine moiety of the mRNA cap structure in vitro
}

\author{
BELINDA WESTMAN, ${ }^{1,5}$ LISA BEEREN, ${ }^{1,2,5}$ EWA GRUDZIEN, ${ }^{3,4,5}$ JANUSZ STEPINSKI, $^{4}$ \\ REMIGIUSZ WORCH, ${ }^{4}$ JOANNA ZUBEREK, ${ }^{4}$ JACEK JEMIELITY, ${ }^{4}$ RYSZARD STOLARSKI, ${ }^{4}$ \\ EDWARD DARZYNKIEWICZ, ${ }^{4}$ ROBERT E. RHOADS, ${ }^{3}$ and THOMAS PREISS ${ }^{1,2}$ \\ ${ }^{1}$ Molecular Genetics Program, Victor Chang Cardiac Research Institute (VCCRI), Darlinghurst (Sydney), NSW 2010, Australia \\ ${ }^{2}$ School of Biotechnology \& Biomolecular Sciences and St. Vincent's Clinical School, University of New South Wales, Sydney, \\ NSW 2052, Australia \\ ${ }^{3}$ Department of Biochemistry and Molecular Biology, Louisiana State University Health Sciences Center, Shreveport, Louisiana \\ 71130-3932, USA \\ ${ }^{4}$ Department of Biophysics, Institute of Experimental Physics, Warsaw University, 02-089 Warsaw, Poland
}

\begin{abstract}
The eukaryotic initiation factor eIF4E binds the mRNA $5^{\prime}$ cap structure and has a central role during translational initiation. eIF4E and the mechanisms to control its activity have oncogenic properties and thus have become targets for anticancer drug development. A recent study (Kentsis et al. 2004) presented evidence that the antiviral nucleoside ribavirin and its phosphorylated derivatives were structural mimics of the mRNA cap, high-affinity ligands for eIF4E, and potent repressors of elF4Emediated cell transformation and tumor growth. Based on these findings, we tested ribavirin, ribavirin triphosphate (RTP), and the dinucleotide RpppG for their ability to inhibit translation in vitro. Surprisingly, the ribavirin-based compounds did not affect translation at concentrations where canonical cap analogs efficiently block cap-dependent translation. Using a set of reporter mRNAs that are translated via either cap-dependent or viral internal ribosome entry sites (IRES)-dependent initiation, we found that these ribavirin-containing compounds did inhibit translation at high (millimolar) concentrations, but there was no correlation of this inhibition with an elF4E requirement for translation. The addition of a ribavirin-containing cap to mRNA did not stimulate translation. Fluorescence titration experiments with eIF4E and the nuclear cap-binding complex CBC indicated affinities for RTP and RpppG that were two to four orders of magnitude lower than those of $\mathrm{m}^{7} \mathrm{GTP}$ and $\mathrm{m}^{7} \mathrm{GpppG}$. We conclude that, at least with respect to translation, ribavirin does not act in vitro as a functional mimic of the mRNA cap.
\end{abstract}

Keywords: translational efficiency; antiviral drugs; in vitro translation; fluorescence quenching; elF4E; cap-dependent translation

\section{INTRODUCTION}

Canonical translation initiation depends strongly on two features present on nearly all cellular mRNAs: the $5^{\prime}$ cap, $\mathrm{m}^{7} \mathrm{GpppN}$, in which 7-methylguanosine is linked by a $5^{\prime}-5^{\prime}-$ triphosphate bridge to the first transcribed nucleoside, and the $3^{\prime} \operatorname{poly}(\mathrm{A})$ tract. The cap structure specifically binds to eukaryotic initiation factor (eIF) $4 \mathrm{E}$, which in turn binds to eIF4G. eIF4G also interacts with the RNA helicase eIF4A to

\footnotetext{
${ }^{5}$ These authors contributed equally to this work.

Reprint requests to: Thomas Preiss, Molecular Genetics Program, Victor Chang Cardiac Research Institute (VCCRI), 384 Victoria Street, Darlinghurst (Sydney), NSW 2010, Australia; e-mail: t.preiss@victorchang.unsw.edu.au; fax: +61-2-9295-8501.

Article published online ahead of print. Article and publication date are at http://www.rnajournal.org/cgi/doi/10.1261/rna.2132505.
}

promote unwinding of mRNA secondary structure, the poly(A)-binding protein (PABP), explaining the synergistic effects of cap and poly(A) tract during de novo initiation, and eIF3, which recruits the $40 \mathrm{~S}$ subunit and associated factors to the $5^{\prime}$ end of mRNA to form the $48 \mathrm{~S}$ initiation complex. Scanning along the mRNA is necessary for initiation codon recognition, which is followed by dissociation of eIFs and joining of the $60 \mathrm{~S}$ subunit to form the elongationcompetent 80S initiation complex (Preiss and Hentze 2003; Sonenberg and Dever 2003). At least three regulatory mechanisms govern the levels, activity, and availability of eIF4E for protein synthesis (von der Haar et al. 2004; Richter and Sonenberg 2005): eIF4E is phosphorylated by Mnk in the MAPK pathway (Scheper and Proud 2002), eIF4E is sequestered by PHAS-I (4E-BP1) in the mTOR pathway (Gingras et al. 2004), and eIF4E gene transcription is increased by a 
variety of mitogenic stimuli (Jones et al. 1996). The involvement of eIF4E in cancer is well documented. Overexpression of eIF4E in cultured mammalian cells produces rapid growth (De Benedetti and Rhoads 1990), causes them to form tumors in nude mice (Lazaris-Karatzas et al. 1990), and prevents apoptosis after growth factor restriction (Polunovsky et al. 1996). Conversely, reduction of eIF4E expression decreases protein synthesis, cell growth rate, and malignant transformation (De Benedetti et al. 1991; Rinker-Schaeffer et al. 1993), including invasiveness, metastasis, and angiogenesis in mice (Graff et al. 1995; Nathan et al. 1997). A wide variety of naturally occurring cancers is associated with overexpression of eIF4E (De Benedetti and Graff 2004). Several studies have shown that eIF4E levels provide a superior indicator of cancer severity, progression, and recurrence than histological changes ( $\mathrm{Li}$ et al. 1997; Franklin et al. 1999). The high levels of eIF4E in breast cancer cell lines have been exploited to selectively kill experimental tumors in mice as a model for gene therapy (DeFatta et al. 2002a,b).

A recent study (Kentsis et al. 2004) was thus met with considerable interest when it identified the broad-spectrum antiviral nucleoside ribavirin (1- $\beta$-D-ribofuranosyl-1,2,4-triazole-3-carboxamide) as an inhibitor of eIF4E. In cells, ribavirin is converted into mono-, di-, and triphosphorylated forms (RMP, RDP, and RTP). Several modes for its antiviral action have been proposed. RMP inhibits IMP dehydrogenase and thus decreases intracellular GTP, leading to reduced viral protein synthesis and/or replication (Streeter et al. 1973; Muller et al. 1977). RMP also blocks guanylyl transferases and thus may inhibit capping of viral transcripts (Cameron and Castro 2001). RTP inhibits viral transcription (Eriksson et al. 1977). RMP is incorporated into viral RNA and serves as a template for $\mathrm{C}$ and $\mathrm{U}$ incorporation with equal efficiency, leading to errors during viral replication (Crotty et al. 2000). Kentsis et al. (2004) postulated that there was structural similarity between ribavirin and 7-methylguanosine that could allow it to interfere with the function of cap-binding proteins. In support of this hypothesis, they reported that RTP binds to recombinant eIF4E with similar affinity as $\mathrm{m}^{7}$ GTP. Fluorescence titration, NMR, competition analysis, and mutational studies further suggested that ribavirin fits in the 7-methylguanosine-binding pocket of eIF4E. Furthermore, Kentsis et al. (2004) presented data that nucleocytoplasmic transport and translation of specific mRNAs that are post-transcriptionally regulated by eIF4E was disrupted after ribavirin-treatment of cells. Finally, they demonstrated that low micromolar doses of ribavirin suppressed eIF4E-mediated oncogenic transformation in cell culture models and inhibited tumor growth in a mouse model of human squamous cell carcinoma (Kentsis et al. 2004). These data offered the potential for new anticancer drugs that target eIF4E, based on ribavirin.

Since the ribavirin triazole moiety offers new possibilities for derivatization not possible with the purine ring, we tested ribavirin, RTP, and the dinucleotide RpppG for their ability to interact with eIF4E, inhibit translation, and substitute for the natural cap when incorporated into mRNA. Surprisingly, we found that none of the ribavirincontaining compounds behaved like their 7-methylguanosine-containing counterparts.

\section{RESULTS AND DISCUSSION}

We sought to establish whether ribavirin and its derivatives could block eIF4E-dependent translation in vitro. For this purpose, we synthesized the ribavirin-based analogs RMP, RTP, and RpppG (Fig. 1A, compounds 1-3). Conventional cap analogs $\left(\mathrm{m}^{7} \mathrm{GTP}, \mathrm{m}^{7} \mathrm{GpppG}\right.$, ApppG) (Darzynkiewicz et al. 1985; Stepinski et al. 1995) were used as reference
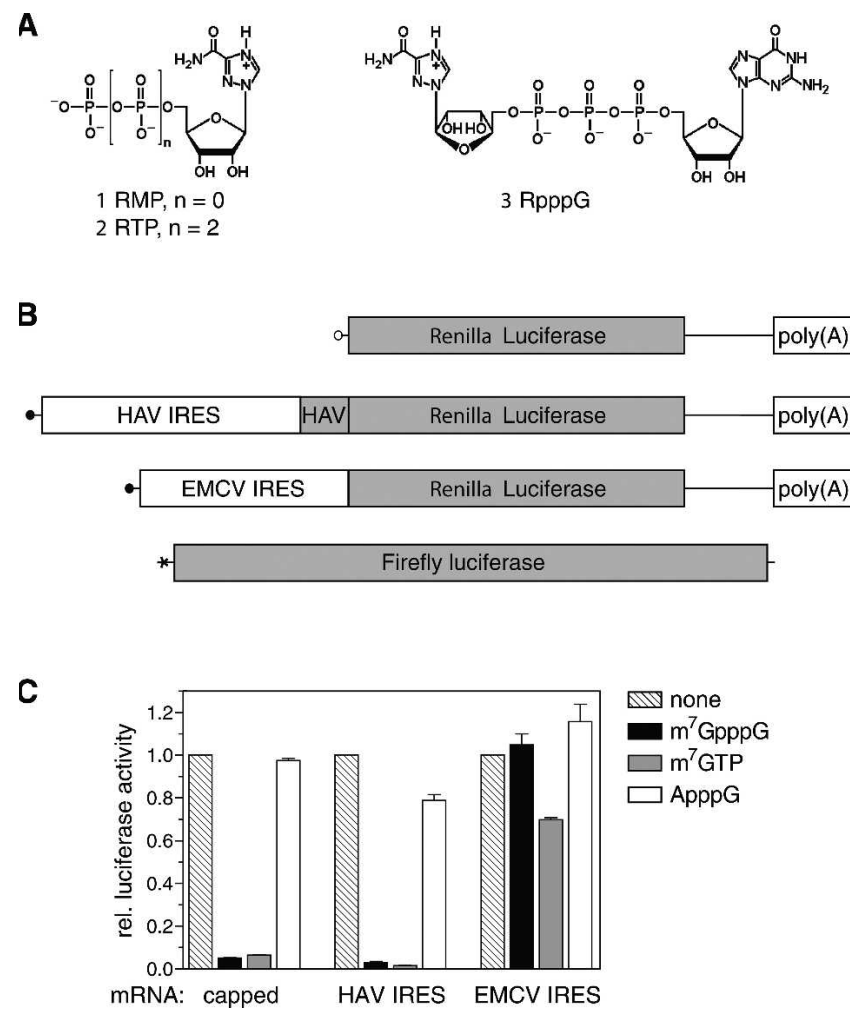

FIGURE 1. Presentation of the main reagents used in this study. (A) Structures of mono- and dinucleotides containing ribavirin. (B) Schematic representation of the different reporter mRNAs used in this study. (Open circle) $\mathrm{m}^{7} \mathrm{GpppG}$-capped, (filled circles) ApppG-capped, (asterisk) various caps. (C) Capped R-luc mRNA, EMCV-R-luc, or HAV-R-luc mRNA were translated in cell-free reactions based on HeLa cell extract. Different cap analogs $\left(\mathrm{m}^{7} \mathrm{GTP}\right.$ [gray bars], $\mathrm{m}^{7}$ GpppG [black bars], ApppG [white bars]) were added to reactions at $0.5 \mathrm{mM}$, together with the mRNA. After incubation for $60 \mathrm{~min}$, reactions were stopped and aliquots taken for R-luc activity measurement as detailed in Materials and Methods. R-luc activities for each type of R-luc mRNA were normalized against parallel control reactions in the absence of cap analog. The graph shows averaged results of several repeat measurements with standard deviation. In the absence of cap analogs, the $\mathrm{m}^{7} \mathrm{GpppG}$-capped R-luc and HAV-R-luc mRNAs were translated with similar efficiency (typically yielding $\sim 25,000$ arbitrary light units over $10 \mathrm{sec}$; approximately two orders of magnitude above background). Translation of the EMCV-R-luc mRNA was approximately fivefold more efficient. 
compounds. Next, we added the cap analogs to cell-free translation reactions based on HeLa cell extracts (Bergamini et al. 2000). Translation conditions were optimized for high cap- and poly(A)-dependence of translation (see MATERIALS AND METHODS). Reactions were programmed with Renilla-luciferase (R-luc) reporter mRNAs synthesized by in vitro transcription and poly(A) tailing (see Fig. 1B). One R-luc mRNA carried a generic $5^{\prime}$ UTR and the $\mathrm{m}^{7} \mathrm{GpppG}$ cap structure. As additional tools for detecting eIF4E-specific inhibition, we also prepared two R-luc mRNAs that contained internal ribosome entry sites (IRESes) in their $5^{\prime}$ UTRs. The IRES-containing mRNAs were capped with the ApppG structure, which protects against mRNA degradation but does not stimulate translation (Bergamini et al. 2000). We chose the encephalomyocarditis virus (EMCV) IRES, which requires all eIFs except eIF4E for initiation (Pestova et al. 1996a,b), and the hepatitis A virus (HAV) IRES, which utilizes all eIFs for its internal initiation mechanism (Brown et al. 1994). HAV IRES-driven translation does not require a $\mathrm{m}^{7} \mathrm{GpppN}$ cap structure on the mRNA, yet depends on eIF4E and is sensitive to addition of cap analogs (Bergamini et al. 2000). Thus, translation initiation at the HAV-IRES requires an unusual function of eIF4E that is inhibited by binding of cap analogs. Both IRES-driven R-luc mRNAs were translated efficiently in our system (>100-fold better than the parental ApppG- capped R-luc mRNA; data not shown). We tested the response of all three R-luc mRNAs to addition of $0.5 \mathrm{mM}$ $\mathrm{m}^{7} \mathrm{GTP}, \mathrm{m}^{7} \mathrm{GpppG}$, or ApppG (Fig. 1C). In line with predictions, we found that translation of capped R-luc and HAV-R-luc mRNAs are both strongly inhibited by the two conventional cap analogs, whereas the EMCV-luc mRNA was mostly resistant. ApppG had little effect on translation of any of the mRNAs.

Next, we tested RTP and RpppG as translational inhibitors of the three R-luc mRNAs (Fig. 2A-C). The reference compounds $\mathrm{m}^{7} \mathrm{GTP}$ or $\mathrm{m}^{7} \mathrm{GpppG}$ maximally inhibited cap-dependent translation at $\sim 0.1 \mathrm{mM}$ (Fig. 2A), with $\mathrm{m}^{7}$ GTP being somewhat more effective than $\mathrm{m}^{7} \mathrm{GpppG}$ (Cai et al. 1999). By contrast, RTP and RpppG were very poor inhibitors of cap-dependent translation, with concentrations of $2 \mathrm{mM}$ and $2.5 \mathrm{mM}$ required to achieve $\sim 50 \%$ inhibition, respectively (Fig. 2A). Thus, roughly 50- to 100-fold higher concentrations of RTP or RpppG were required to achieve $50 \%$ inhibition of cap-dependent translation than with their 7-methylguanosine-containing counterparts. Interestingly, the addition of $2.5 \mathrm{mM}$ RTP caused $\sim 90 \%$ translational inhibition, whereas RpppG at the same concentration resulted in only $50 \%$ inhibition.

RTP inhibited IRES-driven translation marginally more effectively than cap-dependent translation (Fig. 2B-C; 50\% inhibition at $\sim 1 \mathrm{mM})$, suggesting that it does not primarily
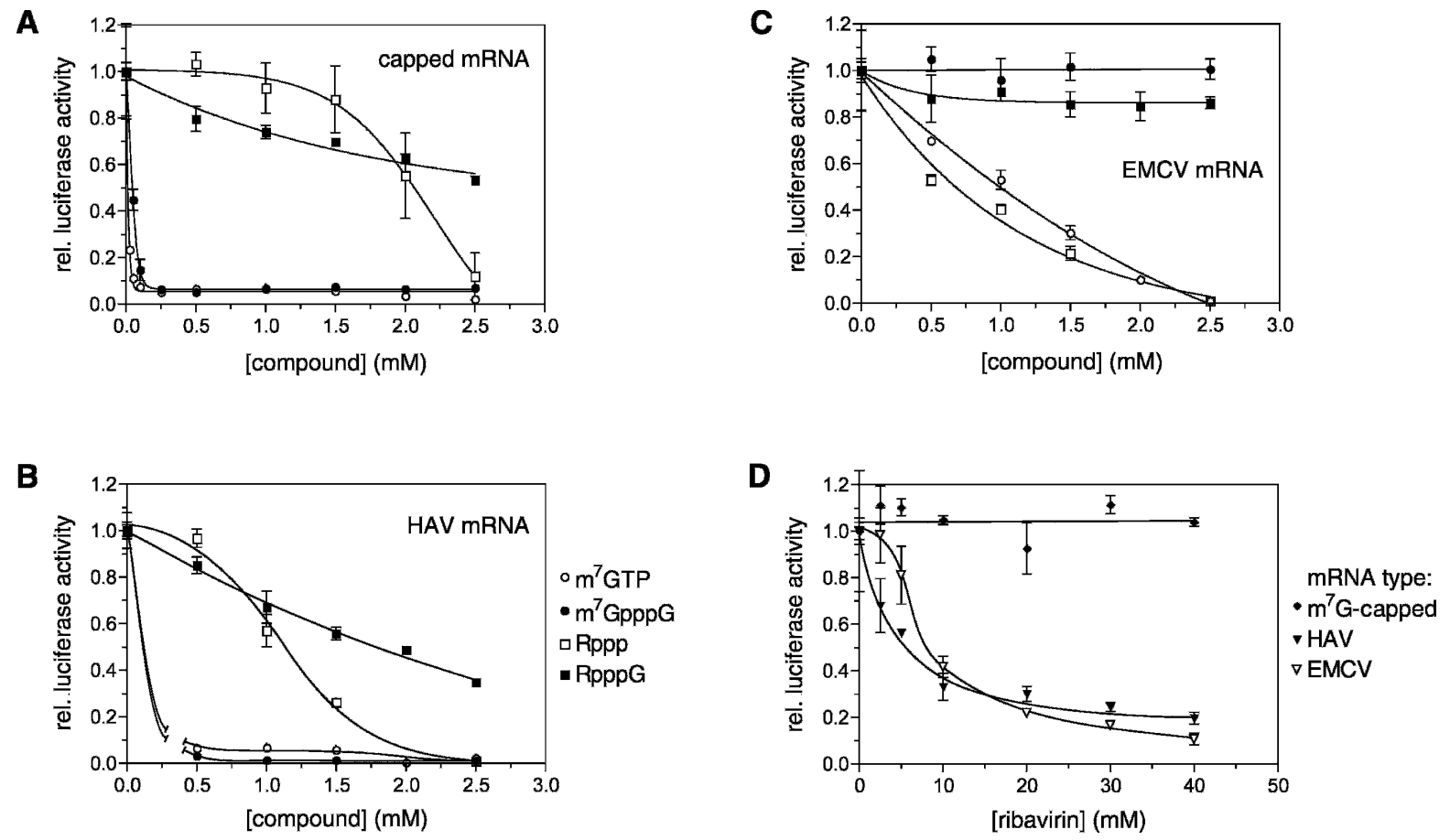

FIGURE 2. Analysis of translation inhibition by ribavirin, RTP, and RpppG. (A-C). Translation of different R-luc mRNAs in the HeLa cell extracts was assayed in the presence of various cap analogs ( $\mathrm{m}^{7} \mathrm{GTP}$ [open circles], $\mathrm{m}^{7} \mathrm{GpppG}$ [filled circles], RTP [open squares], RpppG [filled squares]). Reactions were programmed with capped R-luc mRNA $(A)$, HAV-R-luc mRNA $(B)$, and EMCV-R-luc mRNA $(C)$. $(D)$ HeLa cell extracts were programmed with different R-luc mRNAs ( ${ }^{7}$ GpppG-capped [filled diamonds], HAV-driven [filled triangles], EMCV-driven [open triangles]) in the presence of increasing concentrations of ribavirin. R-luc activities were normalized against parallel control reactions in the absence of added compound. Graphs show averaged results of repeat measurements with standard deviation. 
act through eIF4E. At millimolar concentrations, RTP may act as an inhibitor of an ATP- or GTP-dependent step in translation. In support of this, we note that $\mathrm{m}^{7} \mathrm{GTP}$ had moderate inhibitory effects on EMCV-driven translation that paralleled those of RTP, while neither of the dinucleotides tested had this effect (Fig. 2C). While RpppG was a weak inhibitor of cap- and HAV IRES-driven translation (Fig. 2A,B), it had almost no effect on EMCV IRES-driven translation (Fig. 2C). This may indicate a weak action as a cap mimic at millimolar concentrations. To register any discernable effects with ribavirin itself, we tested even higher concentrations (Fig. 2D). Interestingly, at $\geq 10 \mathrm{mM}$ ribavirin we observed selective inhibition of translation driven by the two IRES elements, while cap-driven translation was resistant to up to $40 \mathrm{mM}$ ribavirin. Thus, the effects of very high concentrations of ribavirin are not consistent with an action through blocking eIF4E function.

It is conceivable that the ribavirin-based analogs were metabolically unstable in the translation system or were sequestered by a binding protein, making them unavailable for interaction with eIF4E. We therefore tested whether ribavirin-based analogs could functionally replace the 7methylguanosine moiety of capped mRNA. Furthermore, viral capping enzymes can utilize RMP to form an RpppN cap on viral mRNAs (Bougie and Bisaillon 2004). We generated three versions of a firefly luciferase (F-luc) mRNA by in vitro transcription, incorporating the conventional $\mathrm{m}^{7} \mathrm{GpppG}$ structure, the RpppG structure, or GpppG (which does not bind eIF4E). These mRNAs were not polyadenylated and were translated in a rabbit reticulocyte lysate system under highly cap-dependent conditions (Stepinski et al. 2001; Jemielity et al. 2003; Grudzien et al. 2004). Firefly luciferase production was linear with both time (data not shown) and mRNA concentration (Fig. 3A). The $\mathrm{m}^{7} \mathrm{GpppG}$ capped mRNA was translated $\sim 15$-fold more efficiently than its RpppG- and GpppG-capped counterparts, indicating that the RTP moiety does not bind to eIF4E.

It was possible that RpppG was not incorporated into the RNA during in vitro transcription by T7 polymerase, or that it was incorporated in the reverse orientation (Stepinski et al. 2001), both of which would prevent it acting as a eIF4Ebinding ligand. We therefore determined the degree to which RpppG is incorporated into RNA during in vitro transcription (\% capping) and the orientation of the cap analog in the RNA (\% correct orientation). The strategy for that was the same as described previously (Stepinski et al. 2001). Briefly, a short RNA was synthesized in the presence of all four NTPs, RpppG, and $\left[\alpha-{ }^{32} \mathrm{P}\right]$ GTP and then digested with RNase T2. Anion exchange HPLC was then used to resolve labeled nucleoside $3^{\prime}$-monophosphates, resulting from incorporation of labeled GMP into internal positions, from $5^{\prime}$-terminal products. The latter are of two types. Uncapped RNAs yield labeled guanosine- $5^{\prime}$-triphosphate $3^{\prime}$-monophosphate (pppGp ${ }^{\star}$, in which ${ }^{*}$ indicates the labeled phosphate group). Ribavirin-capped RNAs can potentially yield two $5^{\prime}$-terminal
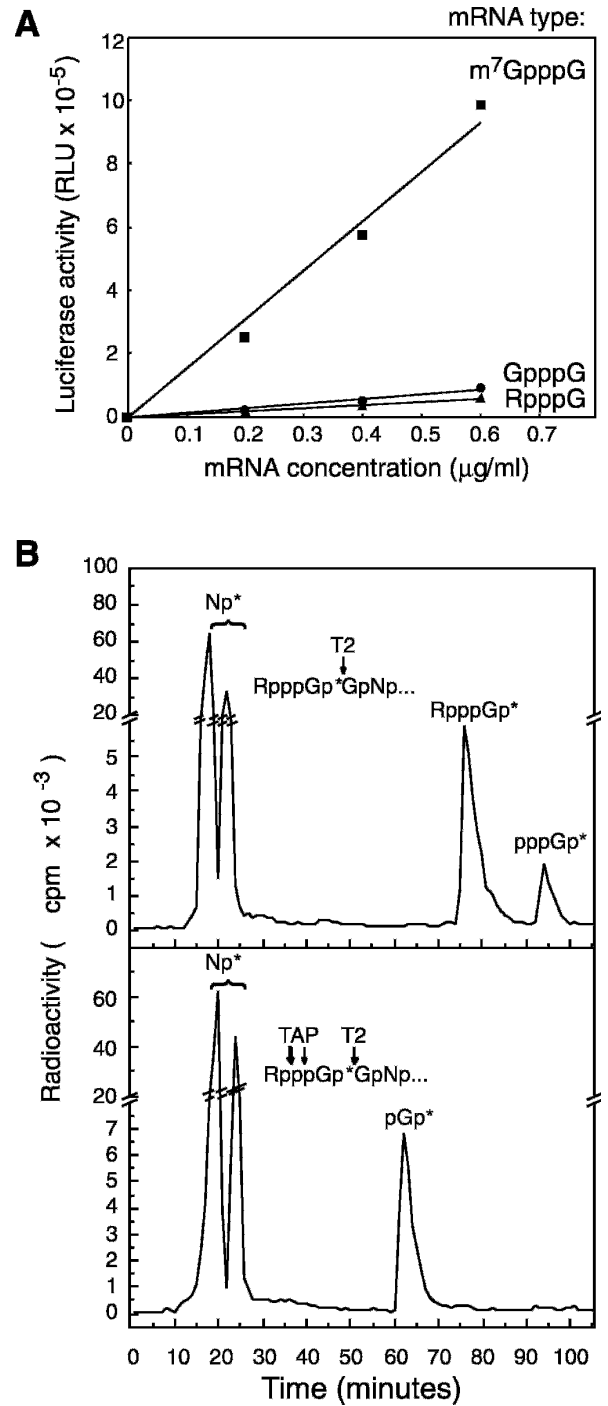

FIGURE 3. RpppG capping of an mRNA fails to stimulate translation. (A) F-luc mRNAs carried either a GpppG (filled circles), $\mathrm{m}^{7} \mathrm{GpppG}$ (filled squares), or RpppG cap (filled triangles) and were translated in a rabbit reticulocyte lysate system. After incubation for $60 \mathrm{~min}$, reactions were stopped and aliquots taken for F-luc activity measurement as detailed in Materials and Methods. (B) RpppG-capped RNAs (48 nt) radiolabeled with $\left[\alpha-{ }^{32} \mathrm{P}\right] \mathrm{GTP}$ during cell-free transcription were digested with either RNase T2 (top) or RNase T2 plus TAP (bottom) followed by anion exchange HPLC. Fractions were collected and the Cherenkov radiation was determined. Assignments of radioactive peaks are based on the elution of the following nonradioactive standard compounds, detected by UV absorption: $5^{\prime}$-RDP (49 min), 5'-GDP (59 $\mathrm{min}), 5^{\prime}$-GTP $\left(80 \mathrm{~min}\right.$ ), and guanosine- $5^{\prime}$-tetraphosphate (95 min). The hydrolysis specificities of RNase T2 and TAP are indicated.

structures, $\mathrm{RpppGp}^{*}$ when the orientation is correct, and $\mathrm{GpppRp}^{\star}$ when the orientation is reversed. Additional digestion of the RNase T2 product with tobacco acid pyrophosphatase (TAP), which hydrolyzes pyrophosphate bonds between the first and second nucleoside moieties, yields two characteristic labeled products, $\mathrm{pGp}^{\star}$ for correct orientation and $\mathrm{pRp}^{*}$ for reverse orientation. As shown in Figure 3B, top panel, the RNA synthesized in the presence of RpppG yielded 
two radioactive peaks (in addition to the four NMPs) upon RNase T2 digestion. Based on the elution times of nonradioactive standards, the peak at 78 min corresponds to RpppGp*, derived from capped RNA, whereas the peak at 95 min corresponds to pppGp ${ }^{*}$, derived from uncapped RNA. The results indicate that transcripts synthesized in the presence of RpppG are $\sim 80 \%$ capped. Digestion with RNase T2 followed by TAP yielded a single peak (in addition to the four NMPs) corresponding to $\mathrm{pGp}^{*}$ (Fig. 3B, bottom panel). Significantly, there was no $\mathrm{pRp}^{*}$ formed. Thus, the caps that are incorporated in the presence of RpppG are $100 \%$ in the correct orientation. Based on these analyses, we conclude that the poor translational activity of RpppG-capped mRNA is not due to a failure to cap or capping in the reverse orientation.

Finally, we tested the affinities of ribavirin and its derivatives to recombinant murine eIF4E (Fig. 4A) and recombinant human nuclear cap-binding complex (CBC; Fig. 4B) in a direct binding assay (Niedzwiecka et al. 2002; Zuberek et al. 2003; Worch et al. 2005). The resulting association constants $\left(K_{a s}\right)$ and corresponding Gibbs free energies $\left(\Delta G^{0}\right)$ are collected in Table 1. $K_{a s}$ and $\Delta G^{0}$ could not be determined for

A

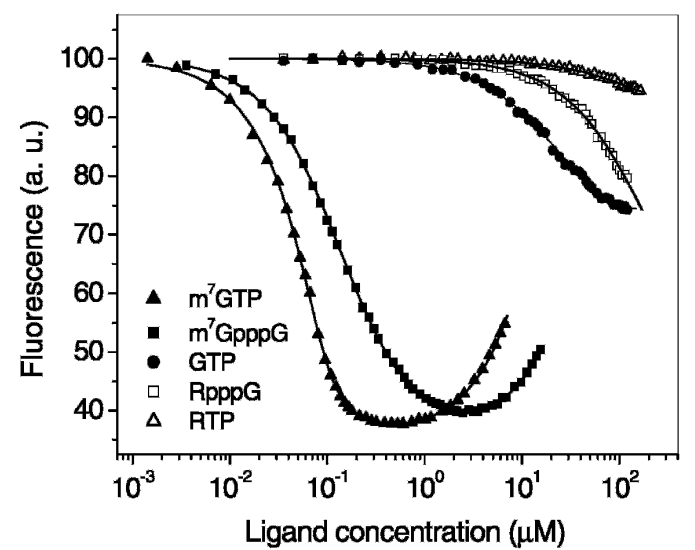

B

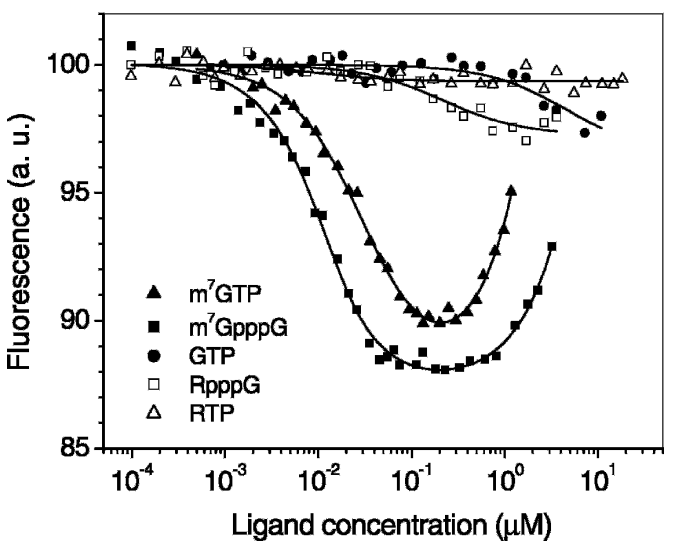

FIGURE 4. Comparison of fluorescence titrations for binding of ribavirin- and 7-methylguanosine cap analogs to murine eIF4E $(A)$ and human $\mathrm{CBC}(B)$. (Filled triangles) $\mathrm{m}^{7} \mathrm{GTP}$, (filled squares) $\mathrm{m}^{7} \mathrm{GpppG}$, (filled circles) GTP, (open squares) RpppG, (open triangles) RTP.
RTP or RpppG, due to a very low affinity of these analogs for both eIF4E and CBC. However, it was possible to estimate the upper limits of the binding parameters of the ribavirin-containing analogs as being approximately the same as for GTP; i.e., two to four orders of magnitude lower than the values for true cap analogs. As an explanation for this difference, we suggest that the positive charge of the 1,2,4-triazole-3-carboxamide does not ensure sufficient cation- $\pi$ stacking with the aromatic side chains inside the binding centers of eIF4E and $\mathrm{CBC}$. Furthermore, there is a loss of hydrogen bonding within the complex compared with the 7-methylguanosine-containing counterparts. In the case of RpppG it appears more likely that the guanine rather than the triazole moiety penetrates the binding slot of the cap binding proteins. Our fluorescence measurements do not concur with similar data gathered by Kentsis et al. (2004) for recombinant murine eIF4E. This may in part be due to different methods of preparing active apoeIF4E, which is a highly unstable protein (see Niedzwiecka et al. [2002] for a detailed discussion on the methodological aspects of eIF4E-cap affinity measurements).

Based on these three independent approaches, we conclude that ribavirin is not a structural or functional mimic of the 7-methylguanosine moiety for translation in vitro. Ribavirin clearly has effects in vivo, but our results make it unlikely that it acts by mimicking the mRNA cap structure.

\section{MATERIALS AND METHODS}

\section{Materials}

Ribavirin was purchased from MP Biomedicals (for chemical syntheses) or Calbiochem (used in Fig. 2D). $\mathrm{m}^{7} \mathrm{GpppG}$, ApppG, GpppG, and $\mathrm{m}^{7} \mathrm{GTP}$ were synthesized as previously described (Darzynkiewicz et al. 1985; Stepinski et al. 1995). Experiments shown in Figure 2A-C were performed with RTP purchased from Jena Biosciences. Analogous results were obtained with the RTP synthesized as detailed below (data not shown). Expression, purification, and assembly of truncated murine eIF4E(28-217) (Zuberek et al. 2003) and human CBC (Mazza et al. 2002) were performed as described.

\section{Chemical synthesis of cap analogs and ribavirin compounds}

Compounds 1-3 (Fig. 1) were isolated from appropriate reaction mixtures by column chromatography on DEAE-Sephadex (A-25, $\mathrm{HCO}_{3}{ }^{-}$form) using a linear gradient of triethylammonium bicarbonate (TEAB, water solution, $\mathrm{pH} 7.5$ ) at $5^{\circ} \mathrm{C}$. Product peaks (as monitored by UV-absorption at $220 \mathrm{~nm}$ and $260 \mathrm{~nm}$ ) were pooled and evaporated to dryness (bath temperature not exceeding $30^{\circ} \mathrm{C}$, ethanol repeatedly added to remove the TEAB buffer). Purity of the products (obtained as TEA salts) was monitored by analytical HPLC with a Supelcosil LC-18-T reverse phase column $(25 \mathrm{~cm})$. The mobile phase was water solution of $0.1 \mathrm{M} \mathrm{KH}_{2} \mathrm{PO}_{4}, \mathrm{pH} 6.0$, with a flow rate of $1.3 \mathrm{~mL} / \mathrm{min}$. Preparative HPLC was performed with the same column but using $0.05 \mathrm{M}$ ammonium acetate $(\mathrm{pH}$ 
TABLE 1. Equilibrium association constants $\left(K_{a s}{ }^{*}\right)$ and the corresponding Gibbs free energies $\left(\Delta G^{9}\right)$ of ribavirin-(R) and 7-methylguanosine cap analog with eIF4E and CBC proteins

\begin{tabular}{|c|c|c|c|c|}
\hline \multirow[b]{2}{*}{ Ligand } & \multicolumn{2}{|c|}{ elF4E $\mathrm{E}^{\mathrm{a}}$} & \multicolumn{2}{|c|}{$\mathrm{CBC}^{\mathrm{b}}$} \\
\hline & $K_{a s}^{*} \times 10^{-6}\left[\mu \mathrm{M}^{-1}\right]$ & $\Delta G^{O}[\mathrm{kcal} / \mathrm{mol}]$ & $K_{a s}^{*} \times 10^{-6}\left[\mu \mathrm{M}^{-1}\right]$ & $\Delta G^{O}[\mathrm{kcal} / \mathrm{mol}]$ \\
\hline $\mathrm{m}^{7} \mathrm{GTP}$ & $136.0 \pm 4.6$ & $-9.381 \pm 0.013$ & $29.7 \pm 23^{c}$ & $-10.012 \pm 0.045$ \\
\hline $\mathrm{m}^{7} \mathrm{GpppG}$ & $10.0 \pm 0.2$ & $-10.903 \pm 0.020$ & $231 \pm 28^{c}$ & $-11.205 \pm 0.071$ \\
\hline GTP & $<0.03$ & $>-6.0$ & $0.33 \pm 0.11^{\mathrm{c}}$ & $-7.39 \pm 0.19$ \\
\hline RTP & $<0.02$ & $>-5.8$ & $<0.1$ & $>-6.7$ \\
\hline RpppG & $<0.01$ & $>-5.4$ & $<1.5$ & $>-8.3$ \\
\hline
\end{tabular}

5.9) as mobile phase. Mass spectra were recorded on a Micromass QToF 1 MS spectrometer using negative electrospray ionization.

\section{Ribavirin 5 '-monophosphate (1, RMP)}

1, RMP was prepared by stirring ribavirin $(150 \mathrm{mg}, 0.61 \mathrm{mmol})$ for $1 \mathrm{~h}$ with $4 \mathrm{~mL}$ of trimethylphosphate and phosphorus oxychloride $(0.2 \mathrm{~mL}, 2.15 \mathrm{mmol})$ at $5^{\circ} \mathrm{C}$. The reaction was quenched with 20 $\mathrm{mL}$ of $1 \mathrm{M}$ TEAB. DEAE Sephadex chromatography using a linear gradient of $0-0.8 \mathrm{M}$ TEAB afforded 1 as a TEA salt, which was used for the next steps without further purification. Mass spectrum $\left(322.99[\mathrm{M}-\mathrm{H}]^{-}\right.$by ESI-MS) of 1 was in accord with the predicted formula weight (324.2 for free acid).

\section{Ribavirin 5 -triphosphate (2, RTP)}

2, RTP was synthesized by stirring a mixture of compound 1 (230 $\mathrm{mg}$, TEA salt, $0.44 \mathrm{mmol})$, imidazole $(240 \mathrm{mg}, 3.53 \mathrm{mmol}), 2,2^{\prime}$ dithiodipyridine $(310 \mathrm{mg}, 1.41 \mathrm{mmol})$, TEA $(60 \mu \mathrm{L})$ and triphenylphosphine (400 mg, $1.5 \mathrm{mmol}$ ) in anhydrous DMF (4 mL) overnight at room temperature. The reaction mixture was poured in a flask containing anhydrous sodium perchlorate $(250 \mathrm{mg})$ dissolved in $25 \mathrm{~mL}$ of acetone. After the solution was allowed to cool for $2 \mathrm{~h}$ at $5^{\circ} \mathrm{C}$, the precipitate was filtered and dried in a vacuum desiccator or over $\mathrm{P}_{4} \mathrm{O}_{10}$. The imidazolide thus obtained was dissolved in DMF $(2.5 \mathrm{~mL})$, and $0.51 \mathrm{~g}(1.07 \mathrm{mmol})$ of tributylammonium pyrophospphate (Sigma) was added. Finally $350 \mathrm{mg}$ of $\mathrm{ZnCl}_{2}$ was added, and the mixture was stirred at room temperature overnight. The reaction mixture was poured into a beaker containing a solution of EDTA $(3 \mathrm{~g})$ in water $(100 \mathrm{~mL})$ and neutralized with $1 \mathrm{M} \mathrm{NaHCO}_{3}$. Chromatographic isolation (linear gradient of 0-1.12 $\mathrm{M}$ TEAB) gave 2 (TEA salt). The crude product was converted to the $\mathrm{Na}^{+}$ salt by ion exchange using a small column of Dowex $50 \mathrm{Wx} 8\left(\mathrm{Na}^{+}\right.$ form), evaporation of the eluate to a small volume, precipitation with ethanol, and centrifugation to give an amorphous white powder. Yield: $80 \mathrm{mg}(29.8 \%)$. Mass spectrum: $482.96[\mathrm{M}-\mathrm{H}]^{-}$by ESIMS, predicted formula weight for 2: 484.2 (free acid).

\section{$P^{1}$-Ribavirin-5' $P^{3}$-guanosine-5' triphosphate (3, RpppG)}

Guanosine 5'-diphosphate imidazolide (Jemielity et al. 2003; 100 $\mathrm{mg}$, purity $88 \%, 0.16 \mathrm{mmol})$, RMP $(1,42 \mathrm{mg}$ as TEA salt, 0.08 $\mathrm{mmol})$, and anhydrous $\mathrm{ZnCl}_{2}$, $(350 \mathrm{mg}, 2.5 \mathrm{mmol})$ were stirred in DMF $(2 \mathrm{~mL})$ for $4 \mathrm{~h}$. Next, the mixture was poured into a beaker containing a water solution of EDTA (170 mg in $20 \mathrm{~mL}$ ) and neutralized with $1 \mathrm{M} \mathrm{NaHCO}_{3}$. Chromatographic isolation on DEAE Sephadex using a linear gradient of TEAB (0-1 M) gave the crude 3 as TEA salt. The product was further purified by preparative HPLC, and after lyophilization, its ammonium salt was finally converted to sodium salt in the same manner as for 2 (yield: $15 \mathrm{mg}, 23 \%$ ). Mass spectrum: $747.85[\mathrm{M}-\mathrm{H}]^{-}$by ESI-MS, predicted formula weight for 3: 749.4 (free acid).

\section{NMR spectroscopy}

${ }^{1} \mathrm{H}$ and ${ }^{31} \mathrm{P}$ spectra were recorded on a Varian UNITYplus 400 $\mathrm{MHz}$ instrument in ${ }^{2} \mathrm{H}_{2} \mathrm{O}$ at $20^{\circ} \mathrm{C}$. ( $\mathrm{s}$ - singlet, $\mathrm{d}$-doublet, $\mathrm{t}$ triplet, $\mathrm{m}$-multiplet due to overlapping).

\section{Ribavirin 5'-triphosphate (2, $\left.\mathbf{R T P} / \mathrm{Na}^{+}, 6 \mathrm{mg}\right)$}

${ }^{1} \mathrm{H}$ NMR $(\delta \mathrm{ppm}): 8.80(\mathrm{H} 5, \mathrm{~s}), 6.03\left(\mathrm{H1}^{\prime}, \mathrm{d}\right), 4.73\left(\mathrm{H} 2^{\prime}, \mathrm{t}\right), 4.58\left(\mathrm{H} 3^{\prime}\right.$, t), $4.39\left(\mathrm{H} 4^{\prime}, \mathrm{m}\right), 4.22\left(\mathrm{H}^{\prime}, \mathrm{H} 5^{\prime \prime}, \mathrm{m}\right) .{ }^{31} \mathrm{P}$ NMR (ppm from external $\left.\mathrm{H}_{3} \mathrm{PO}_{4}\right):-10.95$ (d) for $\mathrm{P} \alpha,-22.47$ (t) for $\mathrm{P} \beta,-9.69 \mathrm{ppm}(\mathrm{d})$ for $\mathrm{P} \gamma$.

\section{$P^{1}$-Ribavirin-5' $P^{3}$-guanosine-5' triphosphate (3, $\left.\mathbf{R p p p G} / \mathrm{Na}^{+}, 1.4 \mathrm{mg}\right)$}

${ }^{1} \mathrm{H}$ NMR ( $\left.\delta \mathrm{ppm}\right): 8.59$ (H5, s, ribavirin), 7.94 (H8, s, guanine), $5.82\left(\mathrm{H1}^{\prime}, \mathrm{d}\right.$, ribavirin), $5.75\left(\mathrm{H1}^{\prime}, \mathrm{d}\right.$, guanosine $), 4.65\left(\mathrm{H} 2^{\prime}, \mathrm{t}\right.$, guanosine $), 4.52\left(\mathrm{H}^{\prime}, \mathrm{t}\right.$, ribavirin $), 4.39\left(\mathrm{H}^{\prime}, \mathrm{m}\right.$, ribavirin and guanosine), 4.19 ( $\mathrm{H} 4^{\prime}, \mathrm{m}$, ribavirin and guanosine), 4.10 ( $\mathrm{H}^{\prime}$, $\mathrm{H} 5{ }^{\prime \prime}, \mathrm{m}$, ribavirin and guanosine). ${ }^{31} \mathrm{P}$ NMR (ppm from external $\mathrm{H}_{3} \mathrm{PO}_{4}$ ): $-11.16(\mathrm{~d})$ for $\mathrm{P} \alpha$, and $\mathrm{P} \gamma,-22.80(\mathrm{t})$ for $\mathrm{P} \beta$.

\section{DNA constructs}

The plasmid pEMCV-RL-TK was created by two-step overlapextension PCR using the Renilla luciferase (R-luc)-encoding pRL-TK (Promega) and pRF-EMCV (a gift from G.J. Goodall, Hanson Centre for Cancer Research, Adelaide, Australia) as templates. Two complementary internal primers, EMCV3 (GGATCAT AAACTTTCGAAGTCATGGTATTATCGTGTTTTTCAAAG) and EMCVLUC5 (CTTTGAAAAACACGATAATACCATGACTTCGAA AGTTTATGATCC), which each contained sequences from the $3^{\prime}$ end of the EMCV IRES and the $5^{\prime}$ end of R-luc (underlined), were used. In addition the two external primers EMCV5 (GTCAGACTG 
CTAGCCCTCGAGCGGGATCAATTCC) and LUCUTR3 (GTGC CACCTGGATCCTTATCG), were designed to amplify from either the $5^{\prime}$ end of the EMCV in a forward direction, or from the BamHI site of pRL-TK in a reverse direction, respectively. The first round of PCR generated the EMCV IRES (using EMCV5, EMCV3, and pRFEMCV) and R-luc portions (using EMCVLUC5, LUCUTR3, and pRL-TK) of pEMCV-RL-TK. These products acted as the template in a second round of PCR (using EMCV5 and LUCUTR3) to produce the full-length product, which was inserted into the NheI and BamHI sites of pRL-TK. The plasmid pHAV-RL-TK was constructed in two steps. First, the R-luc portion was amplified from pRL-TK using the primers LUC5 (GTCAGACTGCTAGCCGAC GGGGTACCACTTCGAAAGTTTATGATCC) and LUCUTR3 and inserted into pRL-TK (digested with BamH1 and NheI). Secondly, the HAV IRES was amplified from the plasmid HAVlucpA (a gift from A. Ostareck-Lederer, Martin Luther University, Halle, Germany) using the primers HAV5 (GTCAGACTGCTAGCGCTTGT AAATATTAATTCCTGCAGG) and HAV3 (CGACGGGGTACCAG TCACTGCAGTCCTATCAACTG) and inserted into the plasmid from the first step, digested with NheI and KpnI. All plasmid constructs were verified by sequencing.

\section{Synthesis of mRNA transcripts}

To synthesize R-Luc mRNAs, pRL-TK and pEMCV-RL-TK were linearized with BamHI, whereas pHAV-RL-TK was linearized with ClaI; digested plasmids were purified from agarose gels using the QiaexII kit (Qiagen). In vitro transcription reactions were performed using the T7 MEGAscript kit (Ambion). Capping was done by adding $6 \mathrm{mM} \mathrm{m}^{7} \mathrm{GpppG}$ or ApppG (GTP concentration was $1.5 \mathrm{mM}$ ). Reactions were incubated for $2 \mathrm{~h}$ at $37^{\circ} \mathrm{C}$ and stopped by the addition of $2 \mathrm{U}$ of DNAse I. The Poly(A) Tailing Kit (Ambion) was used to add a $\geq 150$ base poly(A) tract to transcripts, which were purified using the MEGAclear kit (Ambion). mRNA concentrations were estimated by $\mathrm{A}_{260}$ readings. mRNA quality was inspected by denaturing agarose gel electrophoresis. To synthesize F-luc mRNAs, the plasmid pluc-A+ was digested with SmaI and transcribed with T7 RNA polymerase as previously described (Cai et al. 1999; Jemielity et al. 2003), yielding 1711-nt long mRNAs containing the entire firefly luciferase coding region. A $5^{\prime}$ cap structure (RpppG, $\mathrm{m}^{7} \mathrm{GpppG}$, or $\mathrm{GpppG}$ ) was added to all transcripts.

\section{Analysis of percent capping and cap orientation}

Short RNAs (48 nt) were synthesized in in vitro reactions with T7 polymerase in the presence of RpppG, NcoI-digested pluc-A+, and $\left[\alpha-{ }^{32} \mathrm{P}\right]$ GTP (Stepinski et al. 2001). RNAs were subjected to digestion with RNase T2 (Invitrogen) to analyze percent capping or with TAP (Epicentre Technologies) followed by RNase T2 to determine cap orientation. The products in both cases were resolved by anion exchanged HPLC on a $4.6 \times 250 \mathrm{~mm}$ Partisil 10SAX/25 column (Whatman). The gradient consisted of water for $1 \mathrm{~min}$, a linear gradient of $0-112.5 \mathrm{mM} \mathrm{KH}_{2} \mathrm{PO}_{4}, \mathrm{pH} 4.5$, for $40 \mathrm{~min}$, a linear gradient of $112.5-450 \mathrm{mM} \mathrm{KH}_{2} \mathrm{PO}_{4}$ for $30 \mathrm{~min}$, a linear gradient of $450 \mathrm{mM}-1.5 \mathrm{M} \mathrm{KH}_{2} \mathrm{PO}_{4}$ for $30 \mathrm{~min}$, and isocratic elution at $1.5 \mathrm{M} \mathrm{KH}_{2} \mathrm{PO}_{4}$ for $5 \mathrm{~min}$, all at a flow rate of $1 \mathrm{~mL} / \mathrm{min}$. Fractions of $1 \mathrm{~mL}$ were collected, and the Cherenkov radiation was determined.

\section{In vitro translation reactions and luciferase assays}

For assays using HeLa cell extracts, reactions were performed in a final volume of $10 \mu \mathrm{L}$ containing $4 \mu \mathrm{L}$ of $\mathrm{HeLa}$ cell extract (prepared as described in Bergamini et al. 2000; a gift from M. Hentze and P. Hundsdoerfer, EMBL, Heidelberg, Germany), $2 \mu \mathrm{L}$ of $5 \mathrm{X}$ reaction buffer (containing $80 \mathrm{mM}$ HEPES $\mathrm{pH}$ 7.4, $350 \mathrm{mM}$ KOAc, $10 \mathrm{mM} \mathrm{Mg}(\mathrm{OAc})_{2}, 4 \mathrm{mM}$ ATP, $0.5 \mathrm{mM}$ GTP, $100 \mathrm{mM}$ creatine phosphate, $0.2 \mathrm{mg} / \mathrm{mL}$ creatine kinase, $250 \mu \mathrm{M}$ spermidine, and $30 \mu \mathrm{M}$ amino acids), $0.5 \mu \mathrm{L}$ rRNasin (Promega) and $10 \mathrm{ng}$ R-luc mRNA. The cell extracts were not treated with micrococcal nuclease. Incubations were carried out for $1 \mathrm{~h}$ at $37^{\circ} \mathrm{C}$. Concentrations of $\mathrm{KOAc}$ and $\mathrm{Mg}(\mathrm{OAc})_{2}$ were optimized for cap- and poly(A)dependence of R-luc mRNA translation (data not shown). The Renilla Luciferase Assay System (Promega) was used to measure reporter protein synthesis on a FLUOROstar OPTIMA plate reader (BMG Laboratories). Translation was also performed with the micrococcal nuclease-treated rabbit reticulocyte lysate system (Cai et al. 1999). Optimal cap-dependent translation was achieved at $100 \mathrm{mM} \mathrm{KOAc}$ and $1.4 \mathrm{mM} \mathrm{MgCl}$. Firefly luciferase activity was measured as previously described (Jemielity et al. 2003).

\section{Spectroscopic measurements and data analysis}

Fluorescence titration experiments were performed as described previously (Niedzwiecka et al. 2002).

\section{ACKNOWLEDGMENTS}

We are indebted to Matthias Hentze and Patrick Hundsdoerfer for the gift of HeLa cell extract, and to Stephen Cusack and Catherine Mazza for providing us with human CBC. We thank Greg Goodall, Antje Ostareck-Lederer, David Humphreys, and Nahum Sonenberg for supplying plasmids, and Traude Beilharz and Ania Niedzwiecka for expert advice. This work was supported by grants from the National Health and Medical Research Council, the Australian Research Council, and The Sylvia \& Charles Viertel Charitable Foundation (to T.P.), from the Polish Ministry of Science and Information No. 2 P04A 00628 (to E.D.), from the State Committee for Scientific Research PBZ059/T09/10 (to E.D.) and 3 P04A 02125 (to R.S.), and from the National Institutes of Health, 1R03TW006446-01 (to R.E.R. and E.D.) and NIH 1R01GM20818 (to R.E.R).

Received June 6, 2005; accepted June 27, 2005.

\section{NOTE ADDED IN PROOF}

After this work had been accepted for publication, another study (Yan et al. 2005) reported similar observations.

\section{REFERENCES}

Bergamini, G., Preiss, T., and Hentze, M.W. 2000. Picornavirus IRESes and the poly(A) tail jointly promote cap-independent translation in a mammalian cell-free system. RNA 6: 17811790. 
Bougie, I. and Bisaillon, M. 2004. The broad spectrum antiviral nucleoside ribavirin as a substrate for a viral RNA capping enzyme. J. Biol. Chem. 279: 22124-22130.

Brown, E.A., Zajac, A.J., and Lemon, S.M. 1994. In vitro characterization of an internal ribosomal entry site (IRES) present within the $5^{\prime}$ nontranslated region of hepatitis A virus RNA: Comparison with the IRES of encephalomyocarditis virus. J. Virol. 68: 1066-1074.

Cai, A., Jankowska-Anyszka, M., Centers, A., Chlebicka, L., Stepinski, J., Stolarski, R., Darzynkiewicz, E., and Rhoads, R.E. 1999. Quantitative assessment of mRNA cap analogues as inhibitors of in vitro translation. Biochemistry 38: 8538-8547.

Cameron, C.E. and Castro, C. 2001. The mechanism of action of ribavirin: Lethal mutagenesis of RNA virus genomes mediated by the viral RNA-dependent RNA polymerase. Curr. Opin. Infect. Dis. 14: 757-764.

Crotty, S., Maag, D., Arnold, J.J., Zhong, W., Lau, J.Y., Hong, Z., Andino, R., and Cameron, C.E. 2000. The broad-spectrum antiviral ribonucleoside ribavirin is an RNA virus mutagen. Nat. Med. 6: $1375-1379$.

Darzynkiewicz, E., Ekiel, I., Tahara, S.M., Seliger, L.S., and Shatkin, A.J. 1985. Chemical synthesis and characterization of 7-methylguanosine cap analogues. Biochemistry 24: 1701-1707.

De Benedetti, A. and Graff, J.R. 2004. eIF-4E expression and its role in malignancies and metastases. Oncogene 23: 3189-3199.

De Benedetti, A. and Rhoads, R.E. 1990. Overexpression of eukaryotic protein synthesis initiation factor $4 \mathrm{E}$ in HeLa cells results in aberrant growth and morphology. Proc. Natl. Acad. Sci. 87: 8212-8216.

De Benedetti, A., Joshi-Barve, S., Rinker-Schaeffer, C., and Rhoads, R.E. 1991. Expression of antisense RNA against initiation factor eIF-4E mRNA in HeLa cells results in lengthened cell division times, diminished translation rates, and reduced levels of both eIF-4E and the p220 component of eIF-4F. Mol. Cell. Biol. 11: 5435-5445.

DeFatta, R.J., Chervenak, R.P., and De Benedetti, A. 2002a. A cancer gene therapy approach through translational control of a suicide gene. Cancer Gene Ther. 9: 505-512.

DeFatta, R.J, Li, Y., and De Benedetti, A. 2002b. Selective killing of cancer cells based on translational control of a suicide gene. Cancer Gene Ther. 9: 573-578.

Eriksson, B., Helgstrand, E., Johansson, N.G., Larsson, A., Misiorny, A., Noren, J.O., Philipson, L., Stenberg, K., Stening, G., Stridh, S., et al. 1977. Inhibition of influenza virus ribonucleic acid polymerase by ribavirin triphosphate. Antimicrob. Agents Chemother. 11: 946-951.

Franklin, S., Pho, T., Abreo, F.W., Nassar, R., De Benedetti, A., Stucker, F.J., and Nathan, C.A. 1999. Detection of the protooncogene eIF4E in larynx and hypopharynx cancers. Arch. Otolaryngol. Head Neck Surg. 125: 177-182.

Gingras, A.C., Raught, B., and Sonenberg, N. 2004. mTOR signaling to translation. Curr. Top. Microbiol. Immunol. 279: 169-197.

Graff, J.R., Boghaert, E.R., De Benedetti, A., Tudor, D.L., Zimmer, C.C., Chan, S.K., and Zimmer, S.G. 1995. Reduction of translation initiation factor $4 \mathrm{E}$ decreases the malignancy of ras-transformed cloned rat embryo fibroblasts. Int. J. Cancer 60: 255-263.

Grudzien, E., Stepinski, J., Jankowska-Anyszka, M., Stolarski, R., Darzynkiewicz, E., and Rhoads, R.E. 2004. Novel cap analogs for in vitro synthesis of mRNAs with high translational efficiency. RNA 10: 1479-1487.

Jemielity, J., Fowler, T., Zuberek, J., Stepinski, J., Lewdorowicz, M., Niedzwiecka, A., Stolarski, R., Darzynkiewicz, E., and Rhoads, R.E. 2003. Novel "anti-reverse" cap analogs with superior translational properties. RNA 9: 1108-1122.

Jones, R.M., Branda, J., Johnston, K.A., Polymenis, M., Gadd, M., Rustgi, A., Callanan, L., and Schmidt, E.V. 1996. An essential E box in the promoter of the gene encoding the mRNA cap-binding protein (eukaryotic initiation factor $4 \mathrm{E}$ ) is a target for activation by c-myc. Mol. Cell. Biol. 16: 4754-4764.
Kentsis, A., Topisirovic, I., Culjkovic, B., Shao, L., and Borden, K.L. 2004. Ribavirin suppresses eIF4E-mediated oncogenic transformation by physical mimicry of the 7-methyl guanosine mRNA cap. Proc. Natl. Acad. Sci. 101: 18105-18110.

Lazaris-Karatzas, A., Montine, K.S., and Sonenberg, N. 1990. Malignant transformation by a eukaryotic initiation factor subunit that binds to mRNA $5^{\prime}$ cap. Nature 345: 544-547.

Li, B.D., Liu, L., Dawson, M., and De Benedetti, A. 1997. Overexpression of eukaryotic initiation factor $4 \mathrm{E}$ (eIF4E) in breast carcinoma. Cancer 79: 2385-2390.

Mazza, C., Segref, A., Mattaj, I.W., and Cusack, S. 2002. Largescale induced fit recognition of an $m(7)$ GpppG cap analogue by the human nuclear cap-binding complex. EMBO J. 21: 55485557.

Muller, W.E., Maidhof, A., Taschner, H., and Zahn, R.K. 1977. Virazole (1- $\beta$-D-ribofuranosyl-1,2,4-triazole-3-carboxamide; a cytostatic agent. Biochem. Pharmacol. 26: 1071-1075.

Nathan, C.A., Carter, P., Liu, L., Li, B.D., Abreo, F., Tudor, A., Zimmer, S.G., and De Benedetti, A. 1997. Elevated expression of eIF4E and FGF-2 isoforms during vascularization of breast carcinomas. Oncogene 15: 1087-1094.

Niedzwiecka, A., Marcotrigiano, J., Stepinski, J., Jankowska-Anyszka, M., Wyslouch-Cieszynska, A., Dadlez, M., Gingras, A.C., Mak, P., Darzynkiewicz, E., Sonenberg, N., et al. 2002. Biophysical studies of eIF4E cap-binding protein: Recognition of mRNA $5^{\prime}$ cap structure and synthetic fragments of eIF4G and 4E-BP1 proteins. J. Mol. Biol. 319: 615-635.

Pestova, T.V., Hellen, C.U., and Shatsky, I.N. 1996a. Canonical eukaryotic initiation factors determine initiation of translation by internal ribosomal entry. Mol. Cell. Biol. 16: 6859-6869.

Pestova, T.V., Shatsky, I.N., and Hellen, C.U. 1996b. Functional dissection of eukaryotic initiation factor $4 \mathrm{~F}$ : The $4 \mathrm{~A}$ subunit and the central domain of the $4 \mathrm{G}$ subunit are sufficient to mediate internal entry of $43 \mathrm{~S}$ preinitiation complexes. Mol. Cell. Biol. 16: 6870-6878.

Polunovsky, V.A., Rosenwald, I.B., Tan, A.T., White, J., Chiang, L., Sonenberg, N., and Bitterman, P.B. 1996. Translational control of programmed cell death: Eukaryotic translation initiation factor $4 \mathrm{E}$ blocks apoptosis in growth-factor-restricted fibroblasts with physiologically expressed or deregulated Myc. Mol. Cell. Biol. 16: 6573-6581.

Preiss, T. and Hentze, M.W. 2003. Starting the protein synthesis machine: Eukaryotic translation initiation. Bioessays 25: 12011211.

Richter, J.D. and Sonenberg, N. 2005. Regulation of cap-dependent translation by eIF4E inhibitory proteins. Nature 433: 477-480.

Rinker-Schaeffer, C.W., Graff, J.R., De Benedetti, A., Zimmer, S.G., and Rhoads, R.E. 1993. Decreasing the level of translation initiation factor $4 \mathrm{E}$ with antisense RNA causes reversal of ras-mediated transformation and tumorigenesis of cloned rat embryo fibroblasts. Int. J. Cancer 55: 841-847.

Scheper, G.C. and Proud, C.G. 2002. Does phosphorylation of the capbinding protein eIF4E play a role in translation initiation? Eur. J. Biochem. 269: 5350-5359.

Sonenberg, N. and Dever, T.E. 2003. Eukaryotic translation initiation factors and regulators. Curr. Opin. Struct. Biol. 13: 56-63.

Stepinski, J., Bretner, M., Jankowska, M., Felczak, K., Stolarski, R., Wieczorek, Z., Cai, A.-L., Rhoads, R.E., Temeriusz, A., Haber, D. et al. 1995. Synthesis and properties of $\mathrm{P}^{1}, \mathrm{P}^{2}-\mathrm{P}^{1}, \mathrm{P}^{3}-$ and $\mathrm{P}^{1}, \mathrm{P}^{4}$ dinucleoside di-, tri- and tetraphosphate mRNA $5^{\prime}$-cap analogues. Nucleos. Nucleot. 14: 717-721.

Stepinski, J., Waddell, C., Stolarski, R., Darzynkiewicz, E., and Rhoads, R.E. 2001. Synthesis and properties of mRNAs containing the novel "anti-reverse" cap analogs 7-methyl $\left(3^{\prime}-\mathrm{O}\right.$ methyl)GpppG and 7-methyl (3'-deoxy)GpppG. RNA 7: 14861495.

Streeter, D.G., Witkowski, J.T., Khare, G.P., Sidwell, R.W., Bauer, R.J., Robins, R.K., and Simon, L.N. 1973. Mechanism of action of 1- $\beta$-D-ribofuranosyl-1,2,4-triazole-3-carboxamide 
(Virazole), a new broad-spectrum antiviral agent. Proc. Natl. Acad. Sci. 70: 1174-1178.

von der Haar, T., Gross, J.D., Wagner, G., and McCarthy, J.E. 2004. The mRNA cap-binding protein eIF4E in post-transcriptional gene expression. Nat. Struct. Mol. Biol. 11: 503-511.

Worch, R., Niedzwiecka, A., Stepinski, J., Mazza, C., JankowskaAnyszka, M., Darzynkiewicz, E., Cusack, S., and Stolarski, R. 2005. Specificity of recognition of mRNA $5^{\prime}$ cap by human nuclear cap-binding complex. RNA 11: 1355-1363.
Yan, Y., Svitkin, Y., Lee, J.M., Bisaillon, M., and Pelletier, J. 2005. Ribavirin is not a functional mimic of the 7-methyl guanosine mRNA cap RNA 11: 1238-1244.

Zuberek, J., Wyslouch-Cieszynska, A., Niedzwiecka, A., Dadlez, M., Stepinski, J., Augustyniak, W., Gingras, A.C., Zhang, Z., Burley, S.K., Sonenberg, N., et al. 2003. Phosphorylation of eIF4E attenuates its interaction with mRNA $5^{\prime}$ cap analogs by electrostatic repulsion: Intein-mediated protein ligation strategy to obtain phosphorylated protein. RNA 9: 52-61. 

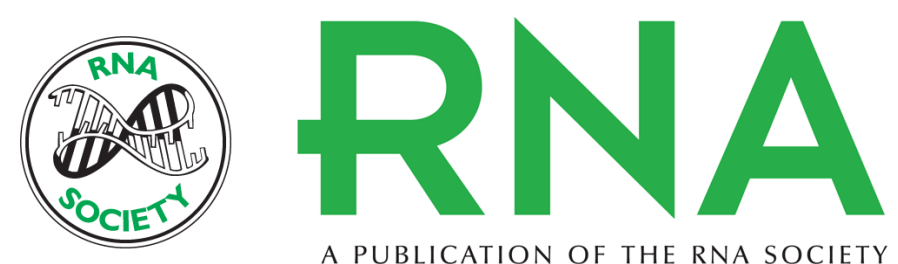

A PUBLICATION OF THE RNA SOCIETY

\section{The antiviral drug ribavirin does not mimic the 7-methylguanosine moiety of the mRNA cap structure in vitro}

BELINDA WESTMAN, LISA BEEREN, EWA GRUDZIEN, et al.

RNA 2005 11: 1505-1513

References This article cites 41 articles, 19 of which can be accessed free at:

http://rnajournal.cshlp.org/content/11/10/1505.full.html\#ref-list-1

\section{License}

Email Alerting Service

Receive free email alerts when new articles cite this article - sign up in the box at the top right corner of the article or click here. 